This item was submitted to Loughborough's Research Repository by the author.

Items in Figshare are protected by copyright, with all rights reserved, unless otherwise indicated.

\title{
The role of the social imaginary in lifestyle migration: employing the ontology of practice theory
}

PLEASE CITE THE PUBLISHED VERSION

http://www.palgrave.com/us/book/9781137328663

\section{PUBLISHER}

Palgrave Macmillan. Selection and editorial matter @ Michaela Benson and Nick Osbaldiston. Individual chapters () Respective authors

\section{VERSION}

AM (Accepted Manuscript)

\section{PUBLISHER STATEMENT}

This work is made available according to the conditions of the Creative Commons Attribution-NonCommercialNoDerivatives 4.0 International (CC BY-NC-ND 4.0) licence. Full details of this licence are available at: https://creativecommons.org/licenses/by-nc-nd/4.0/

\section{LICENCE}

CC BY-NC-ND 4.0

\section{REPOSITORY RECORD}

OReilly, Karen. 2019. "The Role of the Social Imaginary in Lifestyle Migration: Employing the Ontology of Practice Theory”. figshare. https://hdl.handle.net/2134/15692. 
The role of the social imaginary in lifestyle migration: employing the ontology of practice theory (note 1)

\section{Karen O’Reilly}

Abstract

The concept of the social imaginary, discussed by many of the authors in this volume, is an attempt to grapple with the creative, individual and ever-changing nature of the imagination, with the socially-shaped ways in which a place or lifestyle can be imagined, and with the social outcomes of people acting on their imagination in terms of both their own lives and the shaping of places (and new imaginaries). The social imaginary is of central importance to lifestyle migration - a migration seeped in imaginings and romanticism. But 'the social imaginary' is an ambitious concept with an ambitious project, and it has the tendency to become what Billig (2013) has termed a 'noun phrase': imprecise jargon that reifies complexes of things, while discounting people and actions. I argue here that scholars employing the concept would benefit from thinking through its various elements (and actions) more systematically. It is useful to examine the grand ideas, distant structures, sweeping changes, discourses and significations, that pre-exist given agents, and then to relate these to an examination of the level of the daily practices of agents, their tactics and negotiations, in the context of cultural communities. In turn, the concept of the social imaginary can be employed to understand the shaping of new material and social structures and significations, through the ongoing interaction of structure and agency. Thus, I argue, the concept of the social imaginary would benefit from being underpinned by the ontology of practice theory, which provides an ontological basis for understanding both structure and agency (separately conceived) and their interaction in the processes of social life. This chapter then unpacks the role of the social imaginary in lifestyle migration, examining it in terms of the elements of active agency; external structures; internalised structures; practices and outcomes that have been discussed but not elucidated by other authors, especially in this volume. 


\section{Introduction}

Academics in recent decades are developing diverse sets of concepts as part of the endeavour to understand, illustrate and systematically account for the interaction of structure and agency in the ongoing production of social life. The concept of the social imaginary, discussed by many of the authors in this volume, is one such concept. It is an attempt to grapple with the creative, individual and ever-changing nature of the imagination, with the socially-shaped ways in which a place or lifestyle can be imagined, and with the social outcomes of people acting on their imagination in terms of both their own lives and the shaping of places (and new imaginaries). We have seen in this volume how the social imaginary is of central importance to lifestyle migration - a migration seeped in imaginings and romanticism. But 'the social imaginary' is an ambitious concept with an ambitious project, and it has the tendency to become what Billig (2013) has termed a 'noun phrase': imprecise jargon that reifies complexes of things, while discounting people and actions. I argue that scholars employing the concept would benefit from thinking through its various elements (and actions) more systematically. It is useful to examine the grand ideas, distant structures, sweeping changes, discourses and significations, that pre-exist given agents, and then to relate these to an examination of the level of the daily practices of agents, their tactics and negotiations, in the context of cultural communities. In turn, the concept of the social imaginary can be employed to understand the shaping of new material and social structures and significations, through the ongoing interaction of structure and agency.

I argue here that the concept of the social imaginary would benefit from being underpinned by the ontology of practice theory. Practice theory, as I suggest below, provides an ontological basis for understanding both structure and agency (separately conceived) and their interaction in the processes of social life. I have referred elsewhere to social scientists' attempts to interpret a phenomenon in terms of its underlying social processes as the telling of practice stories, and following Stones (2005), I have suggested some analytical concepts through which we can think through more systematically the various steps in a cycle of structuration (O'Reilly, 2012). Crucially 
these involve separating out structure and agency at the conceptual level (albeit always understanding them as co-created over time); identifying the given agents in focus and in context for a given problematic (Stones, 2005); and always retaining a notion of time and process, of the unfolding of events. Here I unpack the role of the social imaginary in lifestyle migration, examining it in terms of the elements of active agency; external structures; internalised structures; practices and outcomes that have been discussed but not elucidated by other authors, especially in this volume.

\section{The concept of the Social Imaginary}

As others in this volume have recognised, socially-shaped imaginaries shape what people desire and how, the ways in which they relate to different environments, and eventually the environment itself (Benson, 2012). Social imaginaries thus influence outcomes and are central to structuration processes. As Griffiths and Maile (this volume) point out, the concept of the social imaginary is complex with different conceptualisations, but broadly speaking, the imaginary is not (necessarily) a reflection of reality, and not necessarily a figment of the imagination, but acknowledges that places come to have shared, collective meanings, mediated through language, symbols, and other significations, and that these meanings have the power to shape reality through the actions of individuals and groups (see especially Castoriadis, 1997 and Appadurai, 1996). Imaginaries are social because they are shared, socially constructed, and have social (and material) impacts. Earlier work on the social construction of space remains a useful way to illustrate how the imaginary is an element in structuration processes. Rob Shields' (1991, p.. 31) notion of spatialisation, for example, spoke of:

the ongoing social construction of the spatial at the level of the imaginary (collective mythologies, presuppositions) as well as interventions in the landscape (for example, the built environment). This term allows us to name an object of study which encompasses both the cultural logic of the spatial and its expression and elaboration in language and more concrete actions, constructions and institutional arrangements. 
Imaginaries are also individual and creative, something people do, but always in negotiation with the field of possibilities (Appadurai, 1996). In the language of practice theory, imaginaries are both actions and structures, shaped by and shaping of agency, and are central to understanding lifestyle migration as an ongoing process. The concept acknowledges both the creative aspects of agency and the role of collective representations in the practice of daily life. Therefore, it involves not only being concerned with how places are imagined before migration, but also embodied and enacted postmigration experiences (Benson, 2011). The concept of the social imaginary helps explain both sociohistorical change, the emergence of the new, and the individual's capacity to 'create a world of (her) own' (Castoriadis, 2007, p.. 208 cited in Griffiths and Maile, this volume).

Nevertheless, the term social imaginary is what Billig has termed a noun phrase - a clump of nouns that has the power to sound official but that in its avoidance of verbs 'transforms people and their doings into things' (Billig, 2013). The use of a noun phrase tends to reify actions and combine complex structures into abstract theoretical constructs, and leads to imprecision. In her work on British migration to France, Benson (2012, p. 1682-3) argues that 'in order to understand how imagination is translated into action, there is a need to focus on the embodied interplay of biographies, individual circumstances, structural preconditions, privileges and constraints, as well as culturally significant imaginings'. The concept of social imaginaries does some of this work, but social imaginaries have a role in the structuration processes in lifestyle migration in different ways, and it is useful to separate out the level of grand ideas, and sweeping historical changes from daily practices of different agents. We also need to retain a notion of time and process. While still recognising that all social structures, including imaginaries, are constituted by and are constitutive of actors, it may well not be these actors at this time that directly formed these sets of ideas that inform this lifestyle migration. I contend that the work of practice theorists can provide us with some of the conceptual work and terminology with which to better understand social imagining as a verb and social imaginaries as a complex of ideas. 


\section{Practice stories}

One of the most profound shifts in social science in recent years has been the shift towards practice or structuration theory as a foundational premise on which research design and understandings are based. This can be quite overt, where academics announce that they are using structuration or practice theory (usually drawing on the work of Anthony Giddens, Pierre Bourdieu, Michel de Certeau and others). Or, in many cases, it is more covert, revealed in the desire to integrate understandings of macro and micro processes, to view motivations in their wider context, or to understand how discourses and significations become embodied and enacted (see Hoey, Osbaldiston, Griffiths and Maile, this volume). Benson (this volume), for example, acknowledges that privilege is both structural condition and reproduced through active agency because of the way it is internalised and has shaped the local social (and even physical) environment; and Vannini and Taggart (this volume) use de Certeau to talk about how the 'new Quietism', in which spirituality is sought by getting 'back to the land', takes shape through the daily practice of tactics that shape distant structures rather than confront them head on.

The shape practice theory takes in empirical work varies with authors, disciplines and even generations (Postill, 2010, p. 6) but the desire to produce narrative, or story-like, accounts that illustrate the interaction of structure and agency over time and space is the same. Academics are increasingly acknowledging that a rigid distinction between structures as external and determining and agency as unfettered free will is no longer tenable. Practice theory thus proceeds out of the common sense idea that:

'all social life is generated in and through social praxis; where social praxis is defined to include the nature, conditions and consequences of historically and spatio-temporally situated activities and interactions produced through the agency of social actors.' (Cohen, 1989, p. 2).

It is the attempt to explicate the ontological and analytical implications of this idea (with a history at least as far back as Aristotle in the Western tradition, Calhoun and Sennett, 2007, p. 7) that has been 
the work of structuration and practice theorists in recent decades, not least because of the past tendency to overlook the centrality of praxis (Cohen, 1989). In my own work (O'Reilly, 2012), in which I have argued for the application of practice theory for migration studies, I draw from the work of Anthony Giddens, Pierre Bourdieu, Rob Stones, and here I will briefly remind readers of the role these authors play in my own elaboration of practice theory.

Anthony Giddens' structuration theory 'provides a set of ontological resources for the formulation of empirically oriented theory and research' (Cohen, 1989, p. 2). Spanning a wide range of publications (eg. Giddens $(1976,1979,1984)$, the key argument is that social structures limit what people can and cannot do, and even what they try or wish to do; but agents continue to have some free will, and the very social structures that enable or constrain in some situations are made and remade by individuals in the process of acting on agency. For Giddens, we therefore cannot even think of agency and structure as ontologically distinct; they are a duality - always interdependent and interrelated. This involves a focus on the praxis of daily life, in which agency and activities are always understood, ontologically, as being located in the context of the nature and consequences of actions. Cohen $(1989$, p. 47) refers to this as the 'decentering' of the subject. Bourdieu's work $(1977,1984,1985,1990)$ also understands social life as made and remade through the everyday, embodied practice of agents, in the context of internalised structural constraints. Crucially, what is often overlooked is that Bourdieu's theory of practice is a general, ontological theory of how social life is shaped through process; it is not meant to be directed towards the analysis of daily practices divorced from their wider context. For Bourdieu, although individuals have the capacity for innovation and creativity, nevertheless the desires shared, the tastes expressed, the choices made, and the actions taken, are always shaped by and shaping of the wider historical and structural context. Individuals and groups are always in practical relations to the world and, therefore, actions are reasonable, sensible, and plausible adjustments to the future, that take into account what is possible and what is not, rather than, as some social scientists understand them, rational calculations or the product of identifiable plans. Furthermore, the constraints and 
opportunities faced by different groups can become so taken for granted that they become internalised as tastes and preferences, embodied as habits and routines, and even shape what is physically possible. The concept of habitus is a central one for the theory of practice, referring to these dispositions, habits, ways of doing things, ways of thinking, and ways of seeing the world that individuals acquire, singly and in groups, as they travel through life (Bourdieu, 1990). Habitus (single and plural) are therefore internalised structures, made and remade through the practice of daily life; they constrain what is possible by the fact of their internalisation rather than by their externality, as is the case with structures more traditionally conceived. Practice thus includes things done habitually, without reflection, but also innovative, critical actions that lead eventually to social change.

Rob Stones (2005) has developed a stronger version of structuration theory that builds on and develops the work of Giddens. Giddens is not always clear how structures might be empirically defined since they are so tied up with agency (Stones, 2005) and his work tends to favour voluntaristic interpretations. Stones especially proposes the conceptual separation of structures and agency (an analytical dualism, but an ontological duality) in order that empirical work can proceed with a specific 'agent in focus' at given stages of the structuration cycle. He thus elaborates Giddens' notion of the concept of the cycle of structuration and identifies four elements for use in empirical studies: external structures, internal structures (both general-dispositional and conjuncturallyspecific), active agency, and outcomes of action (Stones, 2005, p. 189). General-dispositional internal structures can be conceived in much the same way as Bourdieu's habitus. Conjuncturally-specific internal structures acknowledge the element of change, process and creativity that is an aspect of agency. They are the norms, rules and expectations of those around us internalised as we learn how to go on and get by in given circumstances (note 2).

In my elaboration of a meta theoretical framework to guide the telling of migration 'practice stories' (O'Reilly, 2012), I also draw on the concepts of 'communities of practice' and 'situated learning'. Communities of practice (or perhaps cultural communities is a better term) are social groupings 
(family, virtual community, work mates, social club, a partnership, one's neighbours) where individuals come together and need to work out how to get on together (Wenger, 1998). The concept especially helps us understand the social space at the ontological meso level, in-between laws and rules on the one hand, and free choice on the other hand. In communities of practice individuals learn what are the rules of 'the game', in Bourdieu's terms, and how malleable these may be. It is from people with whom we engage in this 'situated learning' (Lave and Wenger, 1991) that we get ideas about how things might be different, and who has the power to change what. Drawing on these themes and theories we are able to identify the following key analytical concepts that can inform empirical research (Stones, 2005; O’Reilly 2012, pp. 23-32):

- External structures are constraints and opportunities that confront a given agent at a given time. They can be separated conceptually into upper level, more distant structures (such as technological advances, broad policy agendas and ideological frames) and more proximate level structures (like laws, rules and organisational arrangements). External structures are also more or less malleable, depending on the power and knowledge of the agent.

- Internal structures can be separated into habitus and conjuncturally-specific internal structures, that become relevant as one learns how to go on in given contexts.

- The practice of daily live takes place within communities of practice (or cultural communities), and here the agent confronts the habitus and conjuncturally-specific internal structures of the other individuals in the context.

- Active agency is then unpredictable but shaped by habitus, and by learning how to go on in specific circumstances. It is also informed by desires and projections, but constrained by external structures.

- The outcome of practice is the reproduction and transformation of social life into newly (re)shaped external and internal structures, dreams and desires.

These concepts each enable a more complex understanding of the role of the social imaginary and the imagination in migration. 


\section{The ability to imagine: an element of agency}

It is to the elements of active agency that I first turn in more depth. Structuration and practice theories are so concerned to emphasise the interaction of structure and agency in the ongoing constitution of society that they tend to overlook, and to provide us with fewer tools with which to understand, the more imaginative and creative aspects of agency (Cohen, 1989). Yet, stories about lifestyle migration are rife with imaginings. Lifestyle migrants, the authors in this volume continually tell us, are motivated to move by their ability to imagine a different way of life. Lifestyle migration is marked by choice rather than lack of it; lifestyle migrants are agents of migration. Korpela (2009) argues that Westerners in Varanasi are in a position to imagine and 'act out' authentic India; British in Spain imagine reinventing the self, leaving their classed backgrounds behind them and creating new lives (Oliver and O'Reilly, 2010). Global nomads emphasise their own agency, freed from the constraints of their past lives (D'Andrea, 2007, pp. 188-9). These migrants tend to seek a fresh start in life or new beginnings, and to imagine a place where this is possible; imaginings are therefore often romantic, heavily laden with meanings, or nostalgic. They also have specific flavours associated with types of good life. British in France imagine a slower pace of life in rural tranquility (Benson, 2011). 'Exurbanites' like Phillip Vannini (this volume) seek 'what they imagine to be a less conventional, less hurried lifestyle', thought they sometimes discover it is not so easily found. Islands, Vannini and Taggart argue, 'give newcomers symbolic material for a fresh start: a clean slate, as it were', and other authors have ascribed this to other liminal spaces, whereas Griffiths and Maile (this volume) introduce to the lifestyle migration literature the idea of 'the imaginative potential of city spaces'.

Many authors have thus discussed what drives lifestyle oriented moves and what sorts of things lifestyle migrants seek. They acknowledge that these imaginings should not be simply understood as push factors that motivate rational actors, but often fail to elaborate theoretically the ontological 
basis of the process. As agency is so central in discussions of lifestyle migration, it is worth spending some time thinking about what it is: how agents imagine and act on the imagination. The recognition of agency as 'the capacity of human beings to shape the circumstances in which they live' emerged through the work of John Locke, Adam Smith, Jeremy Bentham, and other Enlightenment thinkers, but became associated with the pursuit of rational self-interest (Emirbayer and Mische, 1998. P. 965). Kant later posited the notion of a moral and normative aspect to agency, which idea was taken up through the work of later sociological thinkers, such as Schutz, Garfinkel and Goffman. Here, the rational actor was replaced with an individual who responds unthinkingly to social norms, with an emphasis on conformity. More recently, Giddens and Bourdieu, among others, accept that social life adapts and changes and that agents have the power to effect change (some more than others) but they do not develop the tools that enable us to research agency empirically. Stones $(2005, p .336)$ acknowledges agents are creative: active agency includes 'a range of aspects, such as creativity, improvisation and innovation, involved when actors draw upon internal structures in producing practical action'. For him, following Giddens, agents need the power or capability to change things, knowledge about what would happen if they do change things, and enough reflective distance from their current situation to start to think about alternative options. But these authors tend to neglect desire and imagination. Imagination resides in the individual: images can evoke, suggest imaginary futures, portray things, help the imagination in its work, but the imagination itself and the desire this creates are individual.

For Emirbayer and Mische, agency has three elements: the iterational (which is similar to Bourdieu's habitus); the practical-evaluative (which is similar to Stones' conjuncturally-specific internal structures, discussed above); and the projective. This final aspect is what lifestyle migration causes us to reflect on so well: 'Projectivity encompasses the imaginative generation by actors of possible future trajectories of action, in which received structures of thought and action may be creatively reconfigured in relation to actors' hopes, fears, and desires for the future' (1998, p. 971, emphasis in original). Thus we begin to understand the interpretive processes whereby choices are imagined, 
evaluated, and contingently reconstructed by actors in ongoing dialogue with unfolding situations' (Emirbayer and Mische 1998, p.966). The imagination is part of agency, and is essential to understanding human creativity and actions.

Understanding this ontological basis to imagination and desires, and how they lead to active agency, illuminate the role of the trigger factors or watershed events that so many authors have discussed in relation to lifestyle migration (see Benson, 2012; Benson and O’Reilly, 2009a; Hoey, 2005; Korpela, and Salazar, this volume). When agents experience some distance from the habitual, during times of change, upheaval, or instability, there is more space for the imagination and the projective to come into play (Emirbayer and Mische, 1998). As I found in my earlier study, migration to Spain had a sense of continuity - people had often visited the area as tourists, or knew of it from family or friends, or from tourist representations - but 'making the move more permanent tended to signify a break in continuity, often marked by an event in Britain' (O'Reilly, 2000, p. 24). Many migrants cited events that triggered their motivation, such as a failed business, being made redundant, reaching retirement age, deciding to declare their sexuality, a divorce, or the death of a loved one. As Amit (2007) noted, periods of life-cycle transition, such as retirement or completing compulsory education are times when one's cultural capital is threatened, also often trigger migration. These 'fateful moments', where people reach a crossroads in their lives, can create the space for agency but in turn the decisions made at these times can become fateful moments themselves (see Korpela, this volume). Therefore, trigger factors, like the role of socially-shaped imaginings, do not function as simple push factors, rather they are an element in the process of structuration that creates space for creativity, that in turn draws on the imagination and projects possible future scenarios. Agency, Emirbayer and Mische suggest, engages more or less intensely and harmoniously with the contextual environment (cultural communities and other external factors) depending on the what, whom, where and how of the context. Being separated from or having conflicting contexts leads to more reflective phases; but the reflection itself is also an act towards other, imagined, contexts. In 
changing times, some people seek more stability by returning to tradition while others seek alternative futures. It is the content of these alternative futures to which I now turn.

\section{The social imaginary as social structure}

Separating the elements of practice allows us to examine, systematically, where some of the imaginaries that shape lifestyle migration may have come from. There are certain identifiable forms: the search for self-realisation, for escape, and freedom from prior constraints is a central theme; there is a desire to find rurality, a slow pace of life, and quality of life; and sun, sea and relaxation feature quite highly on the list of desirable attributes associated with some geographical destinations (see Benson and O'Reilly, 2009b). As more authors describe other lifestyle migrations, so new themes emerge. Benson and O'Reilly (2009a) identified residential tourism, rural idyll, and bourgeois bohemian forms. In my own current research project we are discovering that Hong Kong lifestyle migrants seek a westernised lifestyle while British in Malaysia imagined exotic cultures and natural surroundings. Griffiths and Maile (this volume) identify the imaginative pull of city or urban life. These 'forms' of social imaginary are best conceptualised analytically as social structures; they are autonomous of the specific agent prior to migration, and have causal influence on actions, both enabling and constraining. This is not to reify them, nor to award them stability or consistency, rather to establish their role at a given juncture. They are perhaps not forms the agent himself or herself will express as such, rather she will personalise them. They are identified as relevant in what the agent does and says, but are recognised by researchers using more distant and abstract-level analysis of patterns or shifts, and theories and concepts.

As Korpela (this volume) acknowledges, it is easy to locate the individualism and reflexivity, and the search for both freedom and self-realisation, that feature in many lifestyle moves, in the theories of Anthony Giddens, Zygmut Bauman, Ulrich Beck and Elisabeth Beck-Gernsheim. According to these theorists, 'our current societies are individualised, the self has become responsible for his/her own life and individuals have internalised the responsibility to choose their own life courses and to 
narrate their individualised biographies' (Korpela, this volume). Bauman (2005), for example, contends that contemporary lifestyles are marked by freedom from the constraints of work and family life. We move in and out of jobs and relationships, seeking short-term gratification for ourselves rather than making any attempt to change society itself for the better. Modern utopias are therefore individualised and changeable. Indeed, in liquid modernity we are 'individuals by decree', and have no choice but to seek out, or hunt, our own personal, privatised 'good life', perhaps through migration to spaces which offer the 'goods' we seek (see O'Reilly, 2009).

Tourism discourses and materially-shaped tourism places are also external structures for a given migrant. Tourism discourses conjure in the imagination the possibility of escaping the routine and mundane aspects of daily life (Graburn, 1989), often in liminal spaces such as beaches and mountains. Or they insinuate the search for authenticity, expected to be discovered in places untouched by modernity and often created or staged to demand (MacCannell, 1999). Tourism also seeks out the adventure, excitement and anonymity of the city; and there are class-based, collective and romantic ways of experiencing the tourist encounter that serve to distinguish travellers and mass tourists (Urry, 2002 and Crick, 1989). Other theorists (eg Urry, 2007) have observed the ubiquity of mobility as opposed to stasis, and the various material structures (facilities, institutions, technologies, infrastructures and built environments) that facilitate and shape this.

Similarly, counter urbanisation literature (as Benson and O'Reilly have discussed, 2009a), understands the concept of the rural idyll as a motivational force behind, and factor shaping the imagination of, migration. It is also possible to see the search for rurality and the middle-class aspiration to get back-to-nature in broader discourses and activities linked to growing awareness of the changing environment, the finite nature of natural resources, and human responsibility. Interestingly, responses, as suggested by the first set of big ideas discussed above, tend to be individualised and self-gratifying rather than blueprints for a better society. More work could be done on where these ideas come from and how they shape actions and imaginations (but see Mantecon, 2008). The point is to recognise how lifestyle migrants' emphasis on individual choice, 
freedom, agency and self-realisation is shaped by social structures external to them at some points in time.

Social imaginaries also take shape in more proximate social structures, that provide opportunities and constraints for migration in ways that are directly relevant to the context of interest. The ideas, discourses, and general cultural shifts discussed above are acted on by agents to attract visitors and (perhaps) migrants and thus the various ways the environment is shaped, marketed and sold may not be the result of the actions of the agents in focus (the migrants). Social imaginaries are enacted by diverse agents and have agency through the marketing of places, through brochures, web pages, signs and symbols. They take shape in the material and built environments, with developers and town planners having a central role. Local and national governments, too, have their role in the granting or not of passports and visas. Griffiths and Maile (this volume) talk of the relationship between the 'ghostly' or 'haunting' quality of Berlin (which can be understood as a broad, upper level structure) and 'the memorializing of urban spaces associated with the victims of state violence' (proximate structures, quite clearly enacted by those who made the memorials).

Tourism is another good example. With the knowledge that some people seek escape, adventure, tranquility, and a return to the past when they travel, governments and tourism agents (and property developers in some cases) have been all too ready to market destinations in ways that will attract tourists and, in turn, lifestyle migrants (see Mantecon, 2008 and Mantecon and Huete, 2008). However, it is also important to remember that proximate social structures depend on the material environment and on historical conditions. One could not imagine or try to create a peaceful retreat in a bustling city (see Griffiths and Maile, this volume) and the materiality of the Lot clearly has some bearing on how that region is imagined (Benson, this volume, and 2012).

\section{Social imaginaries and the habitus}

Social imaginaries are thus understood as the individual capacity to imagine, the socially shaped lifestyles that are imagined, and the possibilities for enacting on those imaginations. As several 
authors have recognised, these imaginings are also internalised into the habitus; they become somewhat taken for granted and unquestioned. Individuals rarely acknowledge that the possibilities offered by a destination and the new lives they seek are socially shaped; the habitus is something understood by social scientists, at the ontological level. But habitus can be observed in the things people say and do and in the ways people act. Researchers have thus witnessed through observations and interviews how the abstract themes and discourses discussed above inform people's habitus and thus their actions. Caroline Oliver (2007, p. 128), for example, examines explicitly how 'age-old mythologies of tourism and travel around the scope and possibility for renewal and reinvention feed into migrant narratives' and infuse their stories of new beginnings, blank slates, and being who you want to be when moving to Spain (see also O'Reilly, 2000). And Korpela (this volume) talks of the ways in which, for Westerners in Goa and Varanasi, individualism is internalised into an ethos of freedom, revealed in their descriptions of the destinations they seek as well as in the ways they understand and enact their new lifestyles.

People aspire to different sets of imaginings for reasons we may never understand; but why people act on some imaginaries and not others is to do with their own personal histories. Remember, individuals have the capacity for future planning but the form the imagination takes is shaped externally (and differently for different people). Each individual has had a personal life history, and unique experiences, and each has internalised different sets of institutional and relational structures in different ways. In this way, the habitus is unique. But, it is also possible to identify group forms of the habitus, elements that have been shaped in certain ways as a result of being a member of a given cultural community. This explains how it is possible to find class-based social imaginaries (noun), and people moving to destinations and expecting, embodying and enacting (verbs) certain things of that destination that can be associated with their social class. As Benson $(2011, p)$ has said of British lifestyle migrants' taste for rural France:

In this rendering the 'taste' - understood here in Bourdieu's (1984) terms as socially constructed - for rural France and the way of life imagined to be available there is a feature 
of British middle-class culture [...] ideas of how to live in rural France, the grounds on which these middle-class actors distinguish themselves from one another, take as their starting point the valorization of rural living.

It is not altogether clear why rurality is important for the British middle classes, or how these ideas have become embodied, how they have shaped the habitus or where they came from. Certainly environmental arguments have been growing over recent decades and with that, even subconsciously, there is a search for quality, purity, and getting back to nature that has been embraced more by middle class than working class groups (perhaps because the former can more readily afford to be choosy). Apparently, it is not the back-breaking work of farm labourers, and the hardships associated with production from the land that migrants seek, but a more gentile and leisured notion of life in rural areas (Benson, 2011), perhaps associated historically with owning the land, the labour and produce. This is an interesting area for further research and theoretical work. Similarly, Griffiths and Maile (this volume) have noticed that there are city-inspired imaginaries, that particularly appeal to the habitus of the young, aspirational classes. Here rapidly-changing cities with emotive histories, such as Berlin, offer the potential for creativity, self-realisation, and a modern bohemianism. We also know tourism destinations appeal (both literally and figuratively) in different ways to different types, different classes, and even different sexualities (Franklin, 2003).

So, we begin to understand the sorts of social imaginaries people seek as being linked to diverse group habitus. But we should remember that where people seek what things will be either enabled or not by many others sets of conditions, such as the natural environment, laws and policies relating to migration, transport links, and the built environment, and numerous other material and social structures. The social imaginary never works alone. Even individual choice has become a social norm, and the ability to act on it depends on the power an agent has.

\section{Power}


We have now located both the imagination and trigger factors in an ontology of practice, and have separated out the social imaginary as an external structure shaped for a migrant prior to migration, and imaginings as internalised structures, shaped by migrants and incorporated into the habitus. However, no practice story is complete without an analysis of power. Lifestyle migrants are powerful groups. First, they are relatively affluent. They may not be affluent relative to the economies of their home countries, or may not remain affluent having moved (see O’Reilly, 2007) - privilege itself is a relative concept problematised by travel (Amit, 2007) - but lifestyle migration tends towards destinations where the cost of living is lower, such as British to Spain or rural France (O'Reilly, 2000; Benson 2011), Westerners to Varanasi (Korpela, 2009), and to South Sinai (Karkabi, 2013), and global nomads in Ibiza and in Goa (D'Andrea, 2007). Similarly, much lifestyle migration follows the trails of earlier colonisations (Benson and O'Reilly, 2009b). As Benson suggests (this volume), it is 'migration made possible by the position of privilege occupied by the migrants in relation to local populations within destinations'.

Postcolonial theory (see Fechter and Walsh, 2010) is a useful way to think about the material and conceptual traces and the continuities of the colonial period into the present; the ways in which internal and external structures have been shaped by these old relationships; and the ways these are perpetuated and resisted in daily practices. In the case of Europeans and North Americans moving to developing countries or to former colonies, as with my own recent work with British lifestyle migrants in Malaysia, their privilege can be witnessed in the ways locals relate to them as well as in their relative wealth and health. Privilege is structured in terms of their ranks as corporate expatriates, or the ranks of their expatriate associates if they have retired to former colonies (Fechter, 2007; Knowles, 2005). Similarly, employing again the concepts and understandings developed above from versions of structuration theory, places have, over time, acquired differential positions in structural hierarchies and this positioning in thus a hard structure, appearing to the agent as external and non-malleable. An individual migrant cannot change the fact some countries are financially more secure than others, for example, or that he/she has more ready access to travel 
visas than people from other countries. Furthermore, the individuals in these places have differential access to resources. Power is thus a macro concept, a broadly conceived set of social structures historically shaped. It is institutionalised in external structures including passport and visa requirements. To give one example, drawing on my own research, in recent decades the Malaysian government has actively encouraged wealthy older people to go there to live (or for long stays) in retirement as a conscious development strategy. They have a visa, the Malaysia My Second Home Visa, especially designed to encourage long-term visitors and individual investment. The visa is promoted on the Ministry of Tourism web site using blatant appeals to the tourist imagination, with mention of good weather, mixed cultures and language, diverse activities, and a rich natural environment. However, the Malaysian government continually manages who takes advantage of this opportunity by monitoring and regularly altering the visa requirements to ensure only the relatively wealthy can apply. Over time this has produced diverse external structures and some unforeseen outcomes: specialist visas have drawn wealthy retirees from around the globe who can demonstrate they have sufficient economic capital; property development has occurred on a grand scale, and led to high price rises in some areas; and the private care industry has developed and targets specific groups (see Ono, 2009). These changes shape the Malaysia, and contribute to the social imaginary that attracts, but also the way it is played out by, the British lifestyle migrants in my research.

Power also takes form in the possession of different types of capital (as in the work of Bourdieu) or knowledge and resources (as in the work of Giddens), or the ability to make a difference, to change things or bring about some desired end, as internal structures. Therefore, no matter what aspect of the social imaginary we are referring to, some people have the resources to move to some places and some people do not. Power is also structured within communities of practice (or cultural communities) as a norm towards agency and free will in western societies, for example. Learning how to go on in diverse sets of circumstances involves thinking about future options and being constrained (or given opportunities) by those around us. Power thus shapes the ability to migrate, to 
act on the imagination, and the experiences and actions post-migration, and the ability to match expectations and imagination.

\section{Social imaginaries, practices and outcomes}

The concept of social imaginaries recognises the habitus alone does not shape how people expect to, and eventually will, relate to a place. As Noel Salazar argues (this volume) migration is ongoing, a practice and process not a single act, and dominant imaginaries can be appropriated or contested, and certainly reshaped. Here we see the important role of what Rob Stones (2005) calls the conjuncturally-specific internal structures, or the ways in which people internalise how how to get on, reconciling their own power and resources, and external and proximate structures in the shape of opportunities and constraints, within diverse sets of cultural community - not forgetting that meaningful communities post migration may well include visiting friends and family, virtual communications (and communities), as well as local face to face interactions. As Keith Halfacree has so eloquently put it (this volume): 'obtaining 'a way of "fitting" seems... no more likely to come from deliberate choice than from accepting a degree of drift, from tacking with events, going with the flow'.

Several studies of lifestyle migration have drawn attention, at least implicitly, to the practice, or the enacting and shaping, of the social imaginary. Caroline Oliver's (2007) older people in Spain don't just talk about being different, they live different lives, making friends quickly, volunteering, taking up new hobbies, and living a slow, relaxed life. In my study (O'Reilly, 2009), we saw British migrants in the Costa del Sol refusing to be rushed, and refusing to be miserable, as they make tourism a way of life. I have shown how tourism, as an imaginary form, takes shape in practice (O'Reilly, 2003). Tourists form part of the cultural communities of the migrants in Spain, as visiting friends and family, as customers in the shared bars and restaurants and on the beach and in other public places. Tourism also shapes the environment they live in, via the provision of services, the infrastructure, 
the availability of goods, and even in the way that Spanish people relate to the British as if they are no more than tourists who stayed longer (see Huete, 2009).

Andreas Huber and I (Huber and O'Reilly, 2004) have shown that older Swiss and British migrants in Spain can find heimat (that elusive sense of home, belonging, and community) without integrating into the Spanish way of life, and without even learning the language, because in their cultural communities (both local and transnational) they work to create what they sought, the caring, security, and satisfying social relations they believe modern life has lost. Griffiths and Maile (this volume) talk of: 'the ways in which the social imaginary representations associated with Berlin - its collective self-representations - are implicated both in individuals' constructions of place and in their embodied encounters with the city'. They show how the city and its social imaginary offer 'possibilities for action, for feeling and being' - more time to spend on creative and cultural activities, or the opportunity to correct the work-life balance. They describe the ways in which the lifestyle migrants have come to see themselves, through moving and living in Berlin, how they learn to get on there and how what I am here calling the conjuncturally-specific internal structures mediate between habitus (prior to migration) and experiences (post migration). Similarly, Vered Amit has discussed how much of these 'escapee' forms of migration (retirement migration, gap year travel, and so on)

involves moving through circuits of movements that are increasingly institutionalized and organized to attract and service Western youths.... This kind of movement therefore offers the possibility of change and self-development, but it encapsulates this potential within a structural bubble of people in similar circumstances (Amit, 2007, p. 7).

Once again, we are drawn to think about the communities of practice and the proximate structures that frame the lives after migration for the agent in focus. Using the terminology from practice stories (O'Reilly, 2012) helps to draw these out more overtly.

Of course, as Cohen and Taylor (1992) warned years ago, escape attempts are often doomed to failure because they get packaged, marketed, and sold back to us for consumption, for profit. This 
has certainly happened in the case of Spanish 'residential tourism'. Mantecon and Huete (2008) draw our attention back to the fact that is not only the migrants that take social imaginaries and shape them. While what we think of as lifestyle migrants to Spain have been shown in numerous studies to seek peace, tranquility and unspoiled landscapes, property developers and government agents have been far too keen to allow rampant development in their rush to attract what they think of as no more than 'residential tourists'. If the goals and imaginaries of the would-be migrants had been harnessed rather than exploited, they suggest, then development and migration could have become a practice that evolved to the benefit of all parties, as well as the natural environment. Here we begin to consider some of the unintended consequences of the enacting out of social imaginaries. The various forms of lifestyle migration identified by researchers (the bohemianism, the new quietism, slowness, tranquillity, self-realisation, the desire to be more in tune with the natural world, and so on) have the potential to effect a better world. But as Caroline Oliver (2007, p. 129) noted, there is a 'contradiction at the heart of the aspirational migration process in the Western world, between the freedom, sociability, and egalitarian possibilities imagined as emerging out of liminal travel and the strong individualism espoused by those engaging in exactly that practice'. Bauman (2005) has identified similar contradictions in the modern hunt for individualised utopia: individual utopias are attempts to change the individual not the world, nor even the society. It seems the power of the lifestyle migrants to effect change, even in their own personal lives, is limited (despite the apparent power and resources enabling the migration in the first place). And so, we see some of the authors in this book referring to the failed goals of lifestyle migration. Hoey suggests that though lifestyle migrants look for places that they imagine as meaningful, this may or may not have much bearing in reality. Noel Salazar notes that they risk failure in their abilities to match imagination and reality: 'in fact, they act within clearly defined fields of possibilities (cf. Bourdieu, 1984)'. Vannini and Taggart illustrate how 'off-gridders' Jim and Judy, who have escaped to a small island off Canada's West coast, fail to be as not independent as they imagined they might be, living off local natural resources and remaining off-grid. They end up getting jobs, and rely quite 
heavily on the internet and diverse advanced technologies in their attempts to create communities. Indeed, many lifestyle migrants cherry-pick the best of advanced societies in their search for escape, and we must remember there is often a supportive system they can return to, and which they profited from enough in the first place to give them the relative wealth to act on their imaginations, as with the British in Malaysia in my own research. Lifestyle migrants rarely have to work the land, or experience all the hardships locals have to bear: Griffiths and Maile's Brits in Berlin continue to enjoy fairly conventional and affluent lives much of the time.

It is thus important to remember that desire and imagination, creativity and socially-structured imaginary, themselves take shape with a wider context of other social structural and material conditions. Korpela (this volume) suggests that what is apparently dropping out, ironically produces the flexible individuals, who shape their own futures and blame themselves rather than the system for their failures, that neoliberal societies require. Lifestyle migration, she suggests, suits the neoliberal agenda. In many cases old hierarchies are simply reproduced (Benson, this volume). And there are broader structural outcomes - shifts in who lives where and therefore economic effects, population shifts, increases in housing costs - and perhaps a new kind of colonialism based on individual self-realisation. Further study of the structural, institutional, and creative outcomes of the social imaginary aspect of lifestyle migration will yield interesting findings.

\section{Conclusion}

In this paper I have shown that the concept of the social imaginary is one that attempts to make sense of agency and structure in interaction: imaginaries are shown in many of the discussions in this volume to be both actions and structures, shaped by and shaping of agency, and central to understanding lifestyle migration as an ongoing process. But as a noun phrase, 'the social imaginary' is sometimes used rather loosely, to combine many elements of the migration process, over time and space, as structures and actions, as constraints and agency, without sufficient precision. I have shown how the social imaginary (and the role of the imagination and consequent actions) can be 
better explicated using the ontology behind a theory of practice. This involves conceptualising structures and actions separately, as a heuristic device, while also always understanding them as interacting in practice. I have thus drawn on the distinction between external structures, internalised structures, practices, communities of practice, active agency, and outcomes as a way of bringing more precision to our understanding of the role of the imagination and to both the social structural and the creative aspects of imagining.

Lifestyle migration is rife with stories about imaginings, and social imaginaries take shape through different elements of its practice. But it is important to remember that to imagine is a verb, it is something individuals have the capacity for, act on, and shape. Both, the work being done on the field of social imaginaries and the work being done in understanding social life as practiced, could benefit from concepts that have been developed to draw attention to this creative and projective aspect of agency. So, within the concept of social imaginaries we need an understanding of individuals who have creative imaginations, the ability to think about and plan for the future, and to act on their ideas. As I have shown, the trigger factors and watershed events described as a motivation in so many studies of migration are then located in a broader sense as creating space for the individual to imagine alternatives. The conditions that shape the imagination, and the extent to which actors have the ability to act on it, remain fascinating areas for further study

I have drawn attention to the ways in which social imaginaries also take the form of social structures, which shape, constrain, and enable actions. These have been witnessed through discourses, traditions, and customs, that pre-exist (given) social actors. Scholars have recognised them in overarching themes like individualism, reflexivity, and self-realisation. But, of course, they are also enacted by human agents, and interact with the material environment. So, for example, tourism as an idea motivates an individual to seek freedom and escape, tourism as an industry 
interacts with amenable natural surroundings, and tourism as an outcome provides proximate structures in the shape of transport links, restaurants and other social institutional amenities.

Social imaginaries are thus richly understood as the individual capacity to imagine, the sociallyshaped lifestyles that are imagined, and the possibilities for enacting on those imaginations. I have also discussed how the concept of the habitus enables us to link social structures at both the distant and more proximate levels to the actions of individuals, in the context of their personal histories. Here, more than anywhere we become aware of social imaginaries as something people do (a verb, people acting based on how they have been shaped by their class background, for example) as well as something that exists externally (a class-based social imaginary, for example). An understanding of social imaginaries as practice also needs to take account of the role of power. Power exists as structures pre-existing the migration, for example, relationships shaped through colonisation have led to some countries being relatively wealthy while others are imagined as exotic and desirable. Power is an individual or group attribute, for example, there are variable amounts of the power to decide to move and the capital with which to resource it. Power also confronts agents as proximate structures, through the ongoing management of the local area, of visas and permits for example.

Finally, social imaginaries are enacted by agents. Migration is not an act but ongoing practice (something people do) and in the process dominant imaginaries are appropriated, contested, and shaped. Lifestyle migrants live out the lives their imaginations had led them to expect; they work to create what they sought, using the act of migration to fuse their self-perception with their lived experiences. But, of course, this is all attempted within the context of social structural conditions and material constraints, including the norms and expectations of diverse cultural communities. The enacting of social imaginaries and the various forms of lifestyle migration we have witnessed in our diverse studies, may have unintended consequences (which, as Benson and Osbaldiston remind us in the introduction to this volume, we have yet to fully examine). The search for slowness, tranquillity, 
authenticity, return to nature, escape from modernity, and self-realisation (and return to true human nature), identified as essential to so many of the imaginaries we have identified, has the potential to effect changes that might improve the world we live in. But social imaginaries are enacted and shaped by other actors than just migrants, and in the end even migrants' power to shape their own lives according to the imagined potentials appears to be limited.

\section{References}

Amit, V. (2007) Structures and Dispositions of Travel and Movement, in V. Amit (ed) Going First Class? New Approaches to Privileged Travel and Movement. (Oxford: Berghahn Books, pp.126-43)

Appadurai, A. (1996) Modernity at Large: Cultural Dimensions of Globalization. (Minneapolis: University of Minnesota Press)

Bauman, Z. (2005) Liquid Life. (Cambridge: Polity)

Benson, M. (2012) 'How culturally significant imaginings are translated into lifestyle migration', Journal of Ethnic and Migration Studies, 38(10): 1681-1696

Benson, M. (2011) The British in Rural France: lifestyle migration and the ongoing quest for a better way of life. (Manchester, Manchester University Press)

Benson, M. \& O'Reilly, K. (2009a) 'Migration and the search for a better way of life: a critical exploration of lifestyle migration', The Sociological Review, 57(4), pp. 608-25.

Benson, M. and O'Reilly, K., eds. (2009b) Lifestyle migration : expectations, aspirations and experiences. (Farnham: Ashgate)

Billig, M. (2013) 'Social sciences and the noun problem'. Higher Education Network. The Guardian Online. http://www.guardian.co.uk/higher-education-network/blog/2013/jul/11/social-sciencesjargon-problem (accessed on 22 July 2013)

Bourdieu, P. (1993) 'Concluding Remarks: For a sociogenetic understanding of intellectual works', in C. Calhoun, E. Li Puma and M. Postone (eds), Bourdieu: Critical Perspectives. (Chicago: University of Chicago Press, pp. 263-75)

Bourdieu, P. (1977) Outline of a theory of practice. (Cambridge: Cambridge University Press)

Bourdieu, P. (1984) Distinction : a social critique of the judgement of taste. (London: Routledge \&Kegan Paul)

Bourdieu, P. (1985) 'The Social Space and the Genesis of Groups'. Theory and Society, 14(6), 723-744.

Bourdieu, P. (1990) The logic of practice. (Cambridge: Polity)

Castoriadis, C. (1997) The Imaginary Institution of Society: Creativity and Autonomy in the Socialhistorical World. (London, Polity Press)

Castoriadis, C. (2007) Figures of the Thinkable. (Stanford California, Stanford University Press)

Cohen, I.J. (1989) Structuration theory : Anthony Giddens and the constitution of social life. (Basingstoke: Macmillan) 
Cohen, S. and Taylor, L. (1992) Escape Attempts. The Theory and Practice of Resistance to Everyday Life. $2^{\text {nd }}$ edn. (London: Routledge)

Crick, M. (1989) 'Representations of International Tourism in the Social Sciences: Sun, Sex, Sights, Savings, and Servility', Annual Review of Anthropology, 18, 307-44

D'Andrea, A. (2007) Global Nomads: Techno and New Age as Transnational Countercultures in Ibiza and Goa (London: Routledge)

Emirbayer, M. and Mische, A. (1998) 'What Is Agency?' American Journal of Sociology, 103(4), 9621023.

Fechter, A.M. \& Walsh, K. (2010) Examining Expatriate Continuities: Postcolonial Approaches to Mobile Professionals, Journal of Ethnic and Migration Studies, 36(8), pp. 1197-210.

Fechter, A.M. (2007) Transnational lives: expatriates in Indonesia (Ashgate , Farnham)

Franklin, A. (2003) Tourism. An Introduction (London: Sage)

Giddens, A. (1976) New rules of sociological method : a positive critique of interpretative sociologies. (London: Hutchinson)

Giddens, A. (1979) Central problems in social theory : action, structure and contradiction in social analysis. (London: Macmillan)

Giddens, A. (1984) The constitution of society : outline of the theory of structuration. (Cambridge: Polity)

Graburn, N. (1989) 'Tourism: The Sacred Journey' in Valene Smith, (Ed) Hosts and Guests. The Anthropology of Tourism. (Philadelphia: Penn.)

Hoey, B. (2005) 'From Pi to Pie: Moral Narratives of Noneconomic Migration and Starting Over in the Postindustrial Midwest', Journal of Contemporary Ethnography, 34:5, 586-624.

Huber, A. and O'Reilly, K. (2004) 'The Construction of Heimat under Conditions of Individualized Modernity: Swiss and British Elderly Migrants in Spain', Ageing \& Society, 24, 327-351.

Huete, R. (2009) Turistas que llegan para quedarse. Una explicación sociológica sobre la movilidad residencial (Tourists who come to stay. A sociological study of residential mobility). Alicante:

Publicaciones Universidad the Alicante

Karkabi, N. (2013) 'Lifestyle Migration in South Sinai, Egypt: Nationalization, Privileged Citizenship and Indigenous Rights' International Review of Social Research.

Knowles, C. (2005) 'Making whiteness: British lifestyle migrants in Hong Kong', in Alexander, C. and Knowles, C. (eds) Making Race Matter: Bodies, Space and Identity. (Basingstoke: Palgrave, pp.90110)

Korpela, M. (2009) More Vibes in India. Westerners in Search of a Better Life in Varanasi (Tampere: Tampere University Press)

Lave, J. and Wenger, E. (1991) Situated learning : legitimate peripheral participation.(Cambridge: Cambridge University Press)

MacCannell, D. (1999) The Tourist. A New Theory of the Leisure Class (University of California Press)

Mantecón, A. and Huete, R. (2008) 'The value of authenticity in residential tourism'. Tourist Studies, 8(3): 359-376

Mantecón, A. (2008) The Experience of Tourism: A Sociological Study of the Process of Residential Tourism. (Barcelona: Icaria) 
O'Reilly, K. (2000) The British on the Costa del Sol. Transnational Identities and Local Communities (London \& New York: Routledge).

O'Reilly, K. (2003) 'When is a Tourist? The Articulation of Tourism and Migration in Spain's Costa de Sol', Tourist Studies, 3:3, 301-317.

O’Reilly, K. (2007) 'Intra-European Migration and the Mobility -Enclosure Dialectic', Sociology, 41:2, 277-293.

O'Reilly, K. (2009) 'Hosts and Guests, Guests and Hosts: British residential tourism in the Costa del Sol', in Obrador Pons, P., Travlou, P. and Crang, M. eds. 2008 Cultures of Mass Tourism: Doing the Mediterranean in the age of banal mobilities. (Farnham: Ashgate)

O'Reilly, K. (2009) 'The children of the hunters: self-realization projects and class reproduction', in Benson, M. and O'Reilly, K. (eds) Lifestyle Migration: Expectations, Aspirations and Experiences. (Farnham: Ashgate, pp.103-120)

O'Reilly, K. (2012) International Migration and Social Theory (London: Routledge)

Oliver, C. (2007) 'Imagined Communitas: Older Migrants and Aspirational Mobility', in Amit, V. (ed) Going First Class? New Approaches to Privileged Travel and Movement. (Oxford: Berghahn Books, pp.126-43)

Oliver, C. and O'Reilly, K. (2010) 'A Bourdieusian Analysis of Class and Migration: habitus and the individualising process'. Sociology, 44(1): 49-66

Ono, M. (2009) 'Japanese lifestyle migration/tourism in Southeast Asia', Japanese Review of Cultural

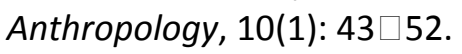

Postill, John. (2010) 'Introduction: Theorising Media and Practice', in B. Brauchler and J. Postill (eds), Theorising Media and Practice. (Oxford: Berghahn Books, pp. 1-34)

Shields, R. (1991) Places on the Margin. Alternative geographies of modernity. (London: Routledge)

Stones, R. (2005) Structuration theory. (Basingstoke: Palgrave Macmillan.)

Urry, J. (2002) The Tourist Gaze (London: Sage)

Urry, J. (2007) Mobilities. (Cambridge: Polity)

Wenger, E. (1998) Communities of practice : learning, meaning, and identity. (Cambridge: Cambridge University Press)

Note 1. Karen O'Reilly's research has been funded by the ESRC on two occasions, grant references R000223944 and RES-000-22-4357

Note 2. Chan et al.(2010) is an excellent example of ethnographic work on childhood obesity that employs Stones' strong structuration theory 